\title{
Kars Müzesi’nde Bulunan Bir Grup Kemer ve Tokaları*
}

\section{Group of Belts and Buckles in the Kars Museum}

\section{Ercan ÇALIŞa}

\section{Ahmet ERK ${ }^{\mathrm{b}}$}

${ }^{a}$ Doç. Dr., Van Yüzüncü Yıll Üniversitesi Edebiyat Fakültesi Sanat Tarihi Bölümü, Van, Türkiye, ercancalis@yyu.edu.tr, ORCID: 00000003-1359-4533

b Doktora Öğrencisi, Van Yüzüncü Y1 Üniversitesi Sosyal Bilimler Enstitüsü Sanat Tarihi, Van, Türkiye, ahmeterk.yyu@gmail.com, ORCID: 0000-0001-5887-659

\begin{abstract}
$\ddot{0 ̈ z}$
Takılar, el sanatlarının önemli bir grubunu oluşturan ve her kültürün sanat ürünleri içerisinde en naif ve zarif olanıdır. Takılar, toplumun sanatsal gelişim düzeyinin belirlenmesinde, sosyal ve kültürel değerlerinin ortaya çıkarılmasında önemli bir yere sahiptir. Kemer ve tokaları bunlar içinde önemli bir grubu oluşturur. Kemer ve tokaları elbise üzerine takılan, elbiseyi tamamlayıcı öğelerden biridir. Elbisenin giyen kişinin üzerine daha iyi oturmasını sağlayan, hançer ve tabaka gibi malzemeleri rahatlıkla takabilmesi için bir gereksinim olarak ortaya çıkmıştır. Zamanla bu işlevinin yanında kadınlar tarafından kullanılan ve elbiseyi tamamlayan bir süs öğesi olmuştur. Kemer ve tokaları dönemin sanatsal özelliklerini yansıtması ve yörelere ait özellikler göstermesi bakımından önemli bir yere sahiptir. Bu çalışmada Kars Müzesi'nde bulunan kemer ve tokaları malzeme, form, yapımında kullanılan teknikler ve süsleme açısından sanat tarihi perspektifine uygun bir şekilde analiz edilmeye çalışılmıştır.
\end{abstract}

Anahtar Kelimeler: El Sanatları, Takı, Maden, Kemer, Toka.

\begin{abstract}
Jewelry is an important group of handicrafts and is the most naive and elegant among the art products of every culture. Jewelry has an important place in determining the artistic development level of the society and revealing its social and cultural values. The most important of these are the belts and buckles worn on the waist. Belts and buckles are one of the complementary elements of the dress that are attached to the dress. It has emerged as a requirement for the wearer to be able to wear materials such as daggers and sheets, which provide a better fit. In time, it has become an ornamental element that complements the dress, especially for women, besides this function. Belts and buckles have an important place in terms of reflecting the artistic characteristics of the period and showing the characteristics of the region. In this study, the belts and buckles in the Kars Museum have been analyzed in terms of materials, forms, techniques used in their production and decoration in accordance with the perspective of art history.
\end{abstract}

Keywords: Handicraft, Jewelry, Metal, Belt, Buckle.

\footnotetext{
* Bu makalede bilimsel araştırma ve yayın etiği ilkelerine uyulmuştur. / In this article, the principles of scientific research and publication ethics were followed.

* Bu çalışma, Van Yüzüncü Yıl Üniversitesi, Bilimsel Araştırma Projeleri Koordinasyon Birimi tarafından SYL-2018-7247 No'lu projeyle desteklenen Ahmet ERK'in "Kars Müzesi'nde Bulunan Etnografik Madeni Takılar" adlı Yüksek Lisans tezinden hareketle "Kemer ve Tokaları" konusunun güncellenmesiyle oluşturulmuştur
} 


\section{GİRIŞ}

El sanatları ürünleri geçmişte yaşamış toplumların ihtiyaçlarıyla gelişmiş (Çalış, 2018: 271) ve zamanla bu toplumların gelenek ve kültürleri ile özdeşleşmiştir (Öztürk, 2012: 1). Bu bağlamda insanlık tarihi boyunca var olan el sanatları ürünleri, gereksinimleri karşılamanın yanı sıra, toplumların yaşayış biçimleri ve kültürel özelliklerini yansıtırlar. El sanatlarının önemli bir grubunu oluşturan takılar ise sanat ürünleri içinde en zarif olanıdır (Megep, 2006: 1). Takı, insanoğlunun el, kol, bel, kafa, kulak, burun ve ayak bileği (Işık, 2010: 22) gibi kişinin giysileriyle bir bütünlük sağlayan ve hoşluk hissi uyandırmak amacıyla birtakım nedenlerle tasarlanmış (Bilgin, 2006: 3) çeşitli maden, doğa ürünleri, değerli ve yarı değerli taşlarla ve buna benzer malzemeler kullanılarak çeşitli formlara sahip süs eşyalarıdır. Takı, tarih boyunca insanlar tarafından süslenmek, daha üstün görünme, hoşluk hissi yaratmak, asalet ve inanç gibi nedenlerle kullanılmıştır. İnsanların dış görünüşüyle şekil alan kolye, bilezik, yüzük, diadem ve kemer gibi temel takılar, değişen zaman, coğrafi bölge ve kültürlere rağmen kullanım amaçları hep aynı olmuşlardır (Aral, 2017: 21). Takıların zamanla form ve süsleme olarak farklılıklar göstermesi ise içinde bulunduğu toplumun özelliklerini aktarması ve birer kültür öğeleri durumunda olduğunu göstermiştir.

Takı serüveni eski çağlara kadar gitmektedir. Anadolu'da takının tarihi Neolitik Çağ’a kadar inmektedir. Diyarbakır Çayönü, Konya Çatalhöyük gibi Neolitik yerleşimlerde yapılan arkeolojik kazılar sonucunda bulunan takılar bunu doğrulamaktadır. Çayönü buluntularında İ.Ö. 7. bin dolaylarına tarihlenen taş boncuklar, takı kakmaları, çengeller, iğneler ve birçok obje çıkarılmıştır (Baydar, 2020: 8). Kazılarla ortaya çıkarılan bu takıların Anadolu'da takı kullanımının ne denli erken hayat bulduğunu göstermesi bakımından önemlidir (Baş \& Çalış, 2020: 92).

$\mathrm{Bu}$ çalışmada, el sanatlarının bir grubunu oluşturan takılar kümesinden bel takıları içerisinde yer alan kemer ve tokaları incelenmiştir. Kemer, bele dolanarak bir toka ile tutturulan, metal, kumaş veya deriden yapılmış, giysilerin tamamlayıcısı olan öğelerinden biridir. Kemerlerin ilk olarak ne zaman ve nerede ortaya çıktığını söylemek güçtür. Ancak elbise üzerine takılan bir aksesuar olduğu için insanoğlunun giysiyi kullanmaya başladığı zamana kadar götürmek olasıdır (Çavuşoğlu, 2002: 12-13). İlk zamanlarda deri ve dokumadan yapılan kemerlerin, giysinin insan vücuduna daha iyi oturması, kişinin yanında bulunan tabaka, hançer gibi malzemeleri rahatlıkla takabilmesi gibi bir gereksinimden ortaya çıktığını söylemek mümkündür.

Bakıra bir miktar kalay eklenerek tunç elde edilmiş, maden sanatında yepyeni bir çığır açılmış (Başak, 2008: 22) ve bu dönem Tunç çağı olarak adlandırılmıştır. Bu dönemde diğer dönemlerin gereksinimlerine ek olarak daha sağlam, hafif, zarif süs eşyaları ve takılar ortaya çıkarılmıştır. Tuncun icadıyla metalürji alanında önemli gelişmeler elde etme olanağının yanında özellikle döküm tekniği olmak üzere gündelik eşyaların yanı sıra takılarda da yeni teknikler kendini göstermiştir (Yılmaz, 2015: 10). İlk madeni kemerler, metallerin işlenmeye başlandığı Tunç çağında ortaya çıktığı ve M.Ö. III. binde kullanıldığı bilinmektedir (Çavuşoğlu, 2002: 13). Mezopotamya'da yapılan kazılar sonucunda metal kemerlerin en erken örnekleri Erken Hanedanlar Dönemi III. Ur'da asker mezarlarında ortaya çıkarılmıştır. Mezarda uzun bir plaka şeklinde bir hançer ve mühür tutturulmuş bir kemer bulunmuştur.

Anadolu'da metal kemerlerin kullanımı ticaret yoluyla Asur Ticaret Kolonileri Çağı'nda başlamıştır. Bu dönemde Anadolu'da kemer kullanıldığını belgeleyen en güzel örnekler arasında kurşun figürinler ve taş kalıplar yer alır (Çavuşoğlu, 2002: 13). Hitit kemerleri hakkında ise M.Ö. 1600’e tarihlendirilen Hitit kabartmaları bilgi vericidir. Bu dönemde kabartmalar üzerinde kadın ve erkeklerin bellerinde kemer kuşaklarının yanı sıra Hitit askerlerinin belinde kalın kemerler yer almaktadır (Türkoğlu, 2008: 22-23). Asur ve Hitit etkisinde kalan Urartular, maden sanatında çok ileri bir seviyeye ulaşmışlardır. Özellikle Urartu kemerleri kalın metal kemerler ve kemerler üzerinde detaylı işçilikler görülmüştür. Kemerler üzerindeki bezemelerde yaşamdan sahneler konu edinmiştir (Berkol, 2019: 48). Balıkesir, Ankara, Eskişehir bölgesinde yaşamış Frigler’in kendilerine özgü giyim tarzları vardı. Yüksek başlıkları üzerinde yer alan başörtüleri, bellerine sarılan kemerin içinden geçirilerek ayak kısımlarına kadar uzanırdı. Ankara Anadolu Medeniyetleri Müzesi’nde bulunan metal kemerler zarif ve özenle işlenmiş Frig kemerlerinin en güzel örneklerini yansıtır (Türkoğlu, 2008: 23). Roma kemerleri metal, kumaş, deri ve kurdelelerden oluşan "fascia pectoralis" (göğüs sargısı) olarak adlandırılmıştır. Romalı kadınlar stola adı verilen tuniklerin göğüs altına bağladıkları "cingulum" ya da "succinta" adı verilen süslü kemerler kullanmışlardır. Erkelerde ise genellikle asker giysilerinde yoğun bir şekilde kullanılmıştır (Berkol, 2019: 50). Bu dönemde deri oyma, kakma ve metal sanatının en güzel örnekleri asker kemerleridir. Özellikle kemerler zırhın bir parçası olarak da önemli bir koruyucu işlev görmüştür. Roma'nın ikiye ayrılmasından sonra doğuda kalan kısma, Batılılar tarafından Bizans denmiştir. Kemer ve tokaları Bizans giyiminin en önemli aksesuarlarından biridir. Özellikle erken dönemde asker elbiselerinin ve resmi giysilerin vazgeçilmez bir parçası olan kemer, bir statü belirtisi olarak görüldüğü için M.S. 382 yılında sivillerin takması yasaklanmıştır. Resmi statüye sahip kişilerin kullandığı kemerler, 6. yüzyılda altından yapılmış kemer tokaları moda halini almıştır. Kemerler değerli taşlarla süslenmiştir. Kemer tokaları erken dönemde menteşeli olarak yapılmış, geç dönemde ise menteşesiz yapılmış ve kayışın tutturulması için halkaları mevcuttur (Günbay, 2019: 63).

Selçuklu dönemi takıları günümüzde oldukça azdır. Selçuklu kemerleri ve kemer tokalarında hayvan figürleriyle süslü ve bunların İran atölyelerinde imal edildiği düşünülmektedir ( Köroğlu, 2004: 50-51). 2002 yılında Ani’de yapılan arkeolojik kazılar 12. yüzyılın sonu ve 13. yüzyılın başlarına tarihlendirilen Büyük Selçuklu dönemine ait Rey ve Merv civarında yapıldığı düşünülen bir kemer bulunmuştur. Aynı kazıda palmet ve rumilerle süslenmiş kemer tokası da bulunmuştur. Tokanın ortasında üçüncü olarak nitelendiren bir şekil yer almaktadır. 13. yüzyıla tarihlendirilen Ahlat seramiklerinde bir kabın üzerinde benzer bir figür bulunmuştur. Bu tokanın İran'da Rey ve Merv kuyumcuları tarafından yapıldığı düşünülmektedir. Kubad-Abad sarayında yapılan arkeolojik kazılarda ise dokuz adet kemer tokası ortaya çıkarılmıştır. Tokalardan dört adeti bronz diğerleri demirden yapılmış, tamamı dövme tekniğindedir (Yavaş, 2012: 2639). Selçuklu dönemine ait altından yapılmış takılar ve 
özellikle kemer ve tokaları Londra British Müzesi, Berlin Devlet Müzesi, Atina Benaki Müzesi’nde yer almaktadır. Selçuklulara ait olduğu düşünülen bu takıların geneli döküm tekniğinde oluşturulmuşken, taş kakma, filigre, kazıma, niello, kabartma ve granüle gibi süsleme teknikleri de bezemesinde kullanılmıştır (Ünlerşen, 2015: 56).

Osmanlı devleti, Selçukluların maden sanatındaki gelişimini devralarak her türlü maden işleme şekillerini bu dönemde geliştirmiştir. Osmanlı devletinde her sanat dalında olduğu gibi kuyumculuk sanatı da saray ve çevresinde gelişme göstermiştir (Çalış \& Erk, 2020: 144). Osmanlı devleti özellikle zengin bir takı geleneğine sahiptir. Bu takılar arasında önemli bir yere sahip kemer ve tokaları yer almaktadır. Osmanlı döneminde kemer giysinin önemli bir aksesuarı olarak erkekler ve kadınlar tarafından kullanılmaktaydı. Osmanlı devletinin ilk dönemlerinde kemer ve tokaları sade olarak yapılmışken, daha sonraları kakma, savat, kazıma, oyma, telkâri ve mıhlama gibi teknikler üst düzeyde kullanılarak mücevher haline getirilmiştir. Özellikle sarayda çalışan görevliler ve askerler için yapılan süslü kemerler, dikkat çekmekteydi (Berkol, 2019: 52). 18. yüzyıla gelindiğinde, Lale Devri olarak bilinen dönemde değerli metallere çeşitli teknikler uygulanarak hazırlanmış taşlı süslü kemerler, tokalara bağlanarak kullanılmıştır. Abdullah Buhari ve Levni'nin bazı minyatürlerinde ayrıntılı bir biçimde bu kemerler betimlenmiştir (Görünür, 2010: 16-17). Minyatürlerdeki bu göz alıcı kemerlerin üzerinde gözüken değerli taşlarla zenginleştirilmiş gümüş plakalar özellikle dikkat çekicidir.

Çalışma kapsamında Kars Müzesi’nde bulunan Selçuklu ve Osmanlı dönemine ait kemer ve tokaları kayıt altına alınmıştır. Söz konusu müzeden gerekli izinler alınarak muhafaza edilen tüm kemer ve tokaları programa dâhil edilmiştir. Form, malzeme ve süsleme kompozisyonları dikkate alınarak benzer eserler programdan çıkartılmış; birbirinden farklı toplam 5 kemer ve 7 kemer tokası olmak üzere toplam 12 eser incelenmiştir. Eserler sanat tarihi perspektifine uygun olarak tanıtılmış ve sanatsal özellikleri belirlenerek tamamlanmaya çalışılmıştır.

\section{2. ÖRNEKLER}

\subsection{Tokalar}

\subsubsection{Gümüş Kemer Tokast}

Selçuklu dönemine ait gümüş kemer tokası dikdörtgen form özelliği göstermektedir. Dört ana levhaya ayrılan eser altın suyuna batırılmış ve hiçbir yeri boş kalmayacak şekilde bezenmiştir. Kulp kısmı ve kemerin takıldı̆̆ı yer tamamen rumi motiflerle süslenmiştir. Tokanın ön yüzünde gövde kısmı yatay ve dikey olarak iki bölüm şeklinde süslenmiştir. Yatay bölüm daha büyük tutulmuş ve diştan zencirek motifi şeklinde dikdörtgen biçiminde bir bordürle çevrelenmiştir. Bunun devamında köşeleri dikdörtgen iki şerit orta kısımda içi içe geçerek dairesel bir form oluşturmuş ve içleri rumi motiflerle bezenmiştir. Dikey olarak düzenlenmiş bölüm iki bordürle çevrelenmiş diş bordür zencirek motifleri ile bezenmiş, iç bordür sade tutulmuştur. Dikey bölümün iç tarafı rumi motiflerle bezenmiştir. Kemer tokasının arka yüzü boydan iki bordürle çevrelenmiştir. Dış bordür zencirek motifi ile bezenmiştir. İkinci bordür sade tutulmuş köşeleri düz orta kısımda birer düğüm oluşturacak biçimde üç bölüme ayrılmıştır. Bölümlerin iç tarafı tamamen rumi motiflerle bezenmiştir (Çiz. 1, Foto. 1-2).

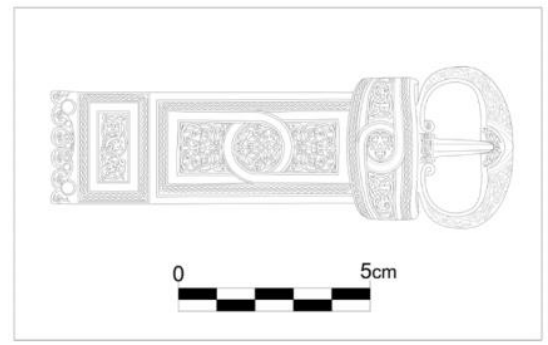

Çizim 1:

Gümüş Kemer Tokası Çizim

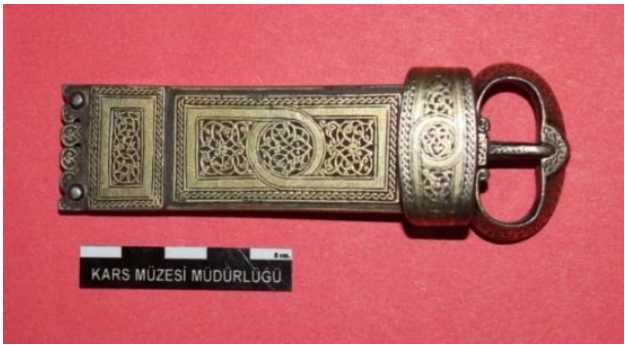

Fotoğraf 1:

Gümüş Kemer Tokası Ön Yüz

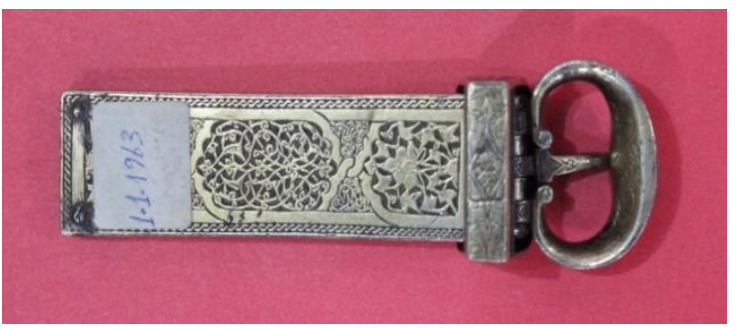

Fotoğraf 2:

Gümüş Kemer Tokası Arka Yüz, Selçuklu Dönemi, Envanter No: 1.1.63/1, Uzunluk: 11,6 cm, Genişlik: 2,9 cm, Kalınlık: 0,6 cm. 


\subsubsection{Gümüş Kemer Tokast}

Dikdörtgen bir form özelliği gösteren kemer tokası Selçuklu dönemine aittir. Kemerin takıldığı kulp kısmı bir menteşe ile tokaya tutturulmuştur. Kemer tokasının menteşe kısmı kıvrık dal motifleri ile bezenmiştir. Tokanın önyüz gövde kısmı üç tane bordürle çevrelenmiştir. Dıştaki bordür zencirek motifleri ile bezenmiştir. İkinci bordür kalın tutulmuş ve sade bırakılmıştır. Üçüncü bordür oldukça ince tutulmuş ve sadedir. Dikdörtgen panonun iç kısmında kazıma tekniğinde kıvrık dallarla rumi motifi yer almaktadır. Kemer tokasının arka yüz kulp kısmında bitkisel süslemeler mevcuttur. Gövde kısmında ise ön yüze göre daha küçük bir dikdörtgen içerisine daha kalın kıvrık dallarla bitkisel süslemeler yer almaktadır. Dikdörtgen çerçeveden gövdenin dört kenarına uzanan birer gül motifi yerleştirilmiştir (Çiz. 2, Foto. 3-4).

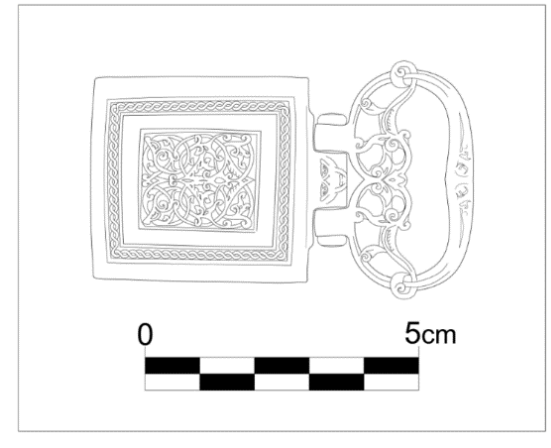

Çizim 2:

Gümüș Kemer Tokası Çizim

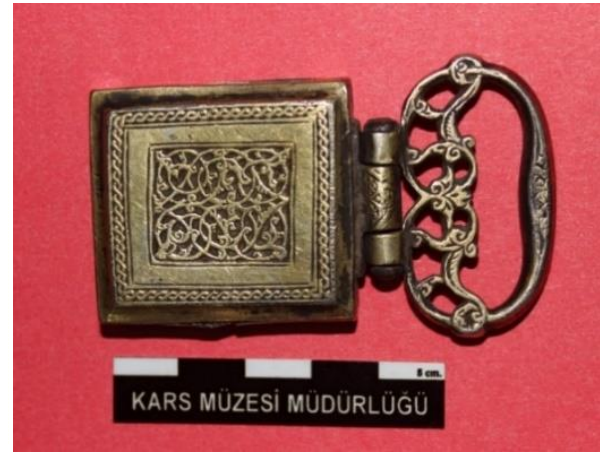

Fotoğraf 3:

Gümüş Kemer Tokası Ön Yüz

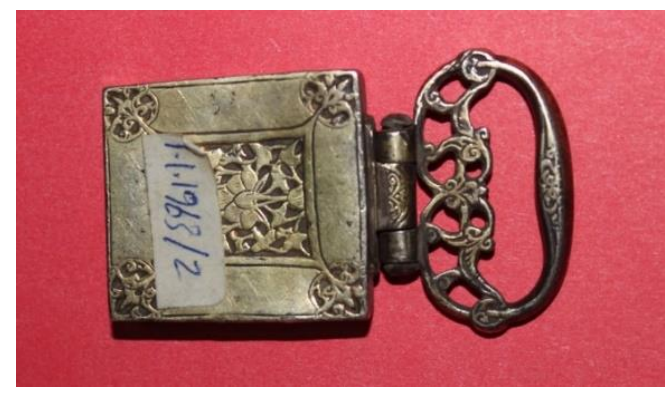

Fotoğraf 4:

Gümüş Kemer Tokası Arka Yüz, Selçuklu Dönemi, Envanter No: 1.1.63/2, Uzunluk: 6,5 cm, Genişlik: $3,5 \mathrm{~cm}$, Kalınlık: 0,7 cm.

\subsubsection{Gümüş Kemer Tokast}

İki parçadan oluşan gümüş kemer tokası yaprak şeklinde simetrik bir biçimde düzenlenmiştir. Kemer tokasının üzeri kabartma tekniğinde bitkisel bezemeli palmet motifi ile süslenmiştir. Kemer tokasının başlı̆̆ı sol tarafa sabitken sağ tarafa kanca ile tutturulmaktadır. İki parçanın birleştiği kısım daha ince tutulmuştur. Kemer tokasının başlığı dairesel bir forma sahip tam ortasında mıhlama tekniğinde kırmızı bir taş yerleştirilmiştir. Kırmızı taşın etrafını saran küçük boyutlu kakma tekniğinde on dört adet mavi boncuk yerleştirilmiştir. Kemer tokasının her bir ucuna küçük dairesel delikler açılmıştır. Büyük olasılıkla bu delikler tokanın sallamaları için açılmıştır. Kemer tokasının arkası oldukça sade tutulmuştur. Tam ve sağlam olan eser üzerinde yıpranmalar görülmektedir (Çiz. 3, Foto. 5).

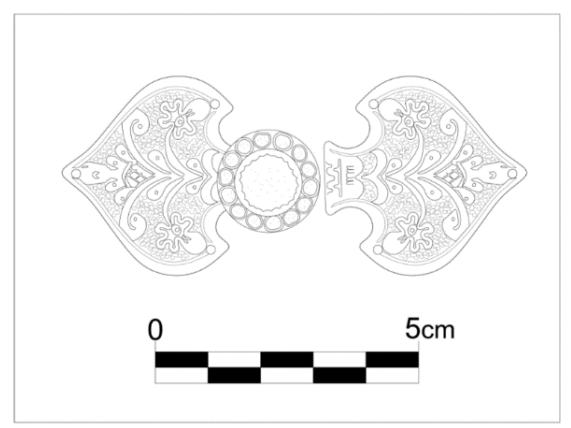

Çizim 3:

Gümüş Kemer Tokası Çizim

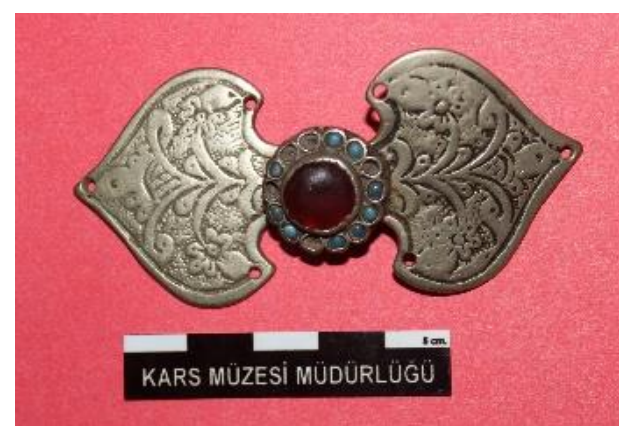

Fotoğraf 5:

Gümüş Kemer Tokas1, Osmanlı Dönemi (18-19. yy), Envanter No: 1.18.79, Uzunluk: $8 \mathrm{~cm}$, Genişlik: $3,7 \mathrm{~cm}$. 


\subsubsection{Gümüs Kemer Tokast}

Damla motifi şeklinde düzenlenmiş kemer tokası iki parçadan oluşmaktadır. Kemer tokası simetrik bir forma sahiptir. İki parçanın birleştiği yerde yarım küre biçiminde dekoratif bir toka ile tutturulmuştur. Yarım küre biçimindeki toka başlığı ajur tekniğinde yapılmış tam ortasında kabartma şeklinde bir kubbecik yerleştirilmiştir. Toka başlığının gövdesine granüle tekniğinde küçük topçuklar yerleştirilmiştir. Kemer tokasının etrafında yarım daire formunda tel sarmalarla bir şerit yer almaktadır. Şeritte yer alan yarım daire şeklindeki tel sarmaların iki ucuna granüle tekniğinde küçük topçuklar yerleştirilmiştir. Kemer tokasının ortası tokanın formunda yapılmış iç ve dış tarafı yarım daire tel sarmalarla çevrili damla motifi biçiminde düzenlenmiştir. Motifin iç tarafı kırmızı ve siyah renkte taşlarla süslenmiştir. Damla motifinin ucunda bir daire etrafında granüle tekniğinde küçük topçuklar ve bir düz bir ters yerleştirilmiş yarım dairelerle bir gül motifi meydana getirilmiştir. Tam ve sağlam olan eser üzerinde oksitlenmeler meydana gelmiştir (Çiz. 4, Foto. 6).

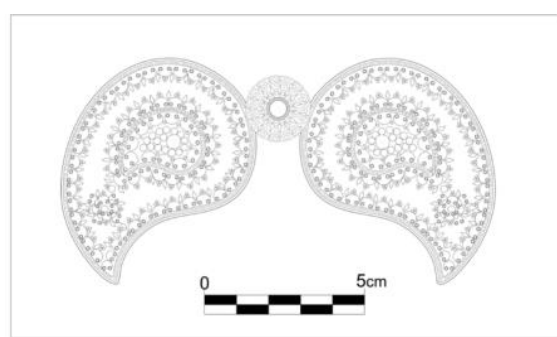

Çizim 4:

Gümüş Kemer Tokası Çizim

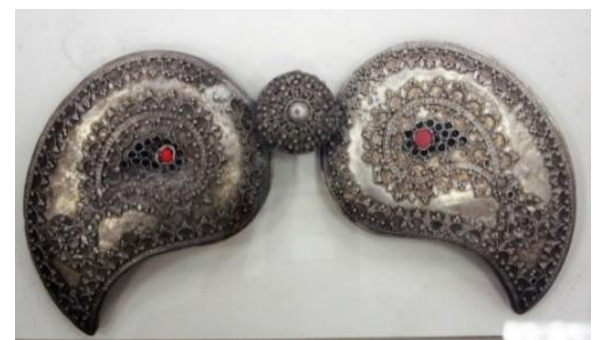

Fotoğraf 6:

Gümüş Kemer Tokası, Osmanlı Dönemi (18-19. yy), Envanter No: 1.10.1973, Uzunluk: $19 \mathrm{~cm}$, Genişlik: $10 \mathrm{~cm}$, Kalınlık: $2 \mathrm{~cm}$.

\subsubsection{Gümüş Kemer Tokası}

Gümüş malzemeden yapılmış kemer tokası ortada oval ve yanlarda iki dikdörtgen plakanın birleştirilmesiyle meydana getirilmiştir. Oval ve dikdörtgen plakaların ortasına birer kubbecik yerleştirilmiştir. Oval plakadaki kubbe daha büyük ve ortasında bir yuva yer almaktadır. Muhtemelen bu yuva içerisine sonradan düşmüş bir taş yerleştirilmiştir. Yuvanın etrafını dairesel bir şerit çevrelemektedir. Kubbenin geri kalan kısmı rumi motifleri ile süslenmiştir. Kubbenin etrafında kalan dairesel form yine rumi motiflerle savat tekniğinde bezenmiştir. Dikdörtgen plakalar simetrik bir biçimde bir bordür içine alınmıştır. Plakaların ortasında yer alan kubbeciklerin üzerinde ve etrafında rumi motifleri ile süslemeler yer almaktadır. Kubbelerin üzerinde yer alan bezemelerin bir kısmı silinmiştir (Çiz. 5, Foto. 7).

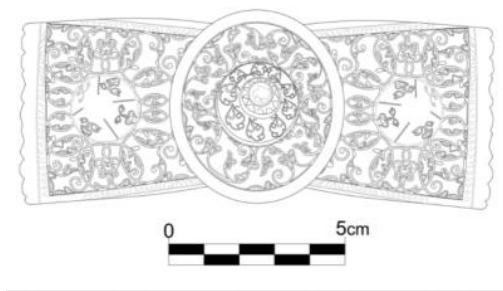

Çizim 5 :

Gümüş Kemer Tokası Çizim

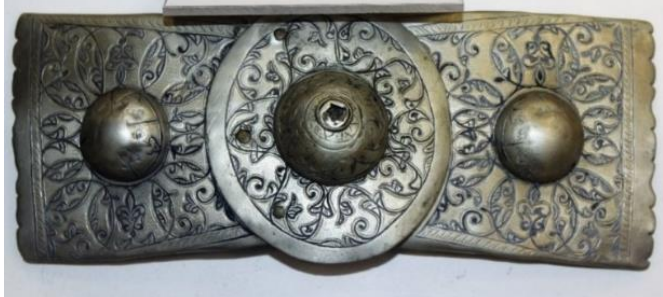

Fotoğraf 7:

Gümüş Kemer Tokası, Osmanlı Dönemi, Envanter No: 2.7.77, Uzunluk: 23,5 cm, Genişlik: $8,5 \mathrm{~cm}$, Daire Çapı: $9,2 \mathrm{~cm}$.

\subsubsection{Gümüş Kemer Tokası}

Kemer tokası dairesel bir forma sahip hafif bombeli simetrik olarak yapılmış iki parçadan oluşmaktadır. Parçalar kanca ile birbirine bağlanmıştır. Dairesel plakanın merkezine tüm yüzeyi kaplayacak şekilde bir gül motifi yerleştirilmiştir. Merkezde bir kubbecik etrafında daire oluşturacak biçimde kabartma tekniğinde yaprak motifleriyle süslenmiştir. Yaprak motiflerini dıştan kabartma tekniğinde bir şerit çevrelemektedir. Kemer tokasının arkası sade bırakılmıştır. Eser günümüzde tam ve sağlamdır (Çiz. 6, Foto. 8). 


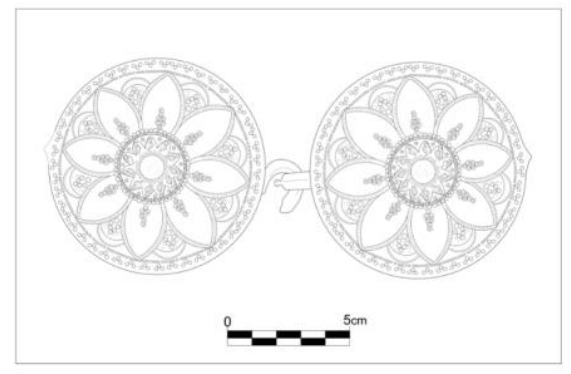

Çizim 6:

Gümüş Kemer Tokası Çizim

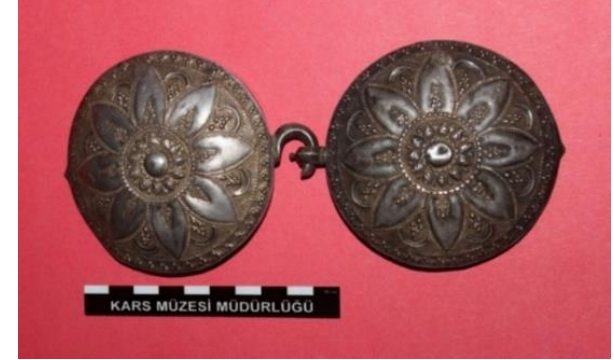

Fotoğraf 8:

Gümüș Kemer Tokas1, Osmanlı Dönemi (19. Yüzyıl), Envanter No: 2.6.2012, Çapı: 8,9 cm, Kalınlık: 0,3 cm.

\subsubsection{Gümüş Kemer Tokası}

Kemer tokası sivri uçlu bir koni biçiminde meydana getirilmiştir. Koninin gövdesi yedigen biçiminde üçgen plakaların birleştirilmesiyle oluşturulmuş ve etrafı papatya yaprağı şeklinde yedi adet yarım daire formunda çevrelenmiştir. Her üçgen levhanın etrafını çevreleyen savat tekniğinde şeritlerle bezenmiştir. Alt kısmında ise yine savat tekniğinde yarım daireler yerleştirilmiş ve ortasına bir nokta konulmuştur. Gövdeyi çevreleyen yarım dairelerde aynı şekilde savat tekniğinde bezenmiştir. Tokanın arka tarafında kemere takılmak üzere kanca yeri mevcuttur. Eser üzerinde silinmeler yer almaktadır (Çiz. 7, Foto. 9).

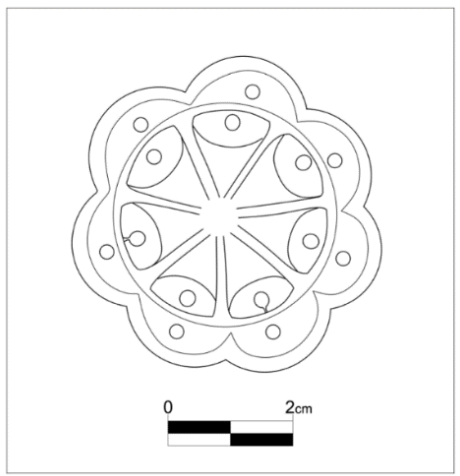

Çizim 7:

Gümüş Kemer Tokası Çizim

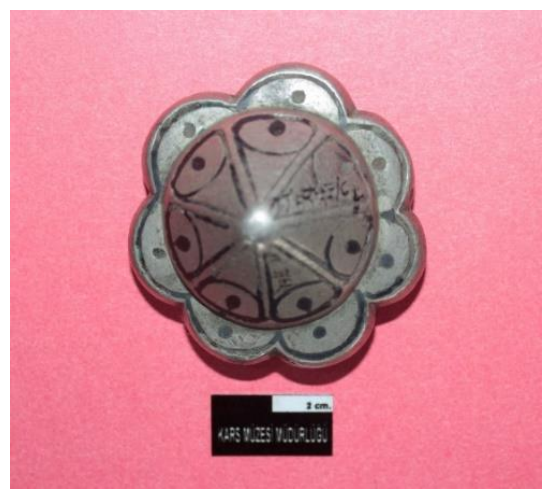

Fotoğraf 9:

Gümüş Kemer Tokası, Osmanlı Dönemi (19. Yüzyıl), Envanter No: 1.20.79, Çapı: 4,5 cm, Yükseklik: $3,5 \mathrm{~cm}$.

\subsection{Kemerler}

\subsubsection{Gümü̈ş Kemer}

Kemer, toplam otuz dört adet levhadan meydana getirilmiştir. Kemeri oluşturan levhalar, Kars Kafkas yöresinde sıkça rastlanan erkekli dişili levhaların birleştirilmesiyle oluşturulmuş ve bir toka ile son bulmaktadır. Levhaların birbirine tutturulması ve takan kişinin daha rahat hissetmesi için kemerin iç kısmına deri malzeme eklenmiştir. Kemerin kaş kısmı yarım silindir bir forma sahip ortasında savat tekniğinde süslenmiş altı köşeli bir yıldız yerleştirilmiş, sağ ve sol tarafında birbirine dolanan dört adet lale motifi yer almaktadır. Kaş kısmının alt ve üst bölümü de birer lale motifi ile süslenmiştir. Kemer tokası, iki kancalı olup kemerin bir tarafına sabitlenmiş ve diğer tarafında da bu kancaların tutturulması için kanca yerleri mevcuttur. Kemerin kuşak bölümünde yer alan ve birbirini tamamlayan erkekli levhalarda bir büyük, dişili levhalarda ise bir küçük kubbecik biçiminde kabartmalar yer almaktadır. Kabartmaların etrafı rumi motifleri ile bezenmiştir. Kemer levhalarının alt kısmında yan yana dizilerek bir şerit halinde kemeri çevreleyen içe doğru kıvrılmış plakalar yer almaktadır (Çiz. 8, Foto. 10-11).

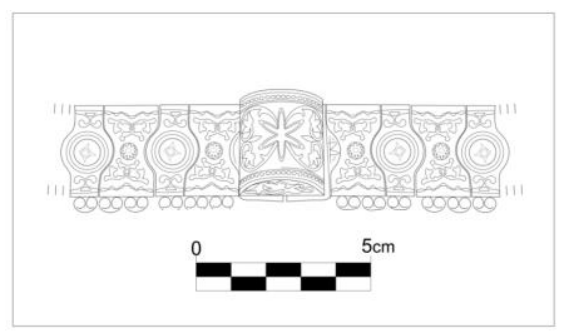

Çizim 8:

Gümüş Kemer Çizimi

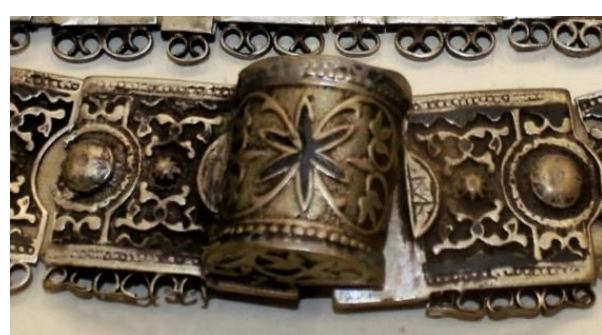

Fotoğraf 10:

Gümüş Kemer Detayı 


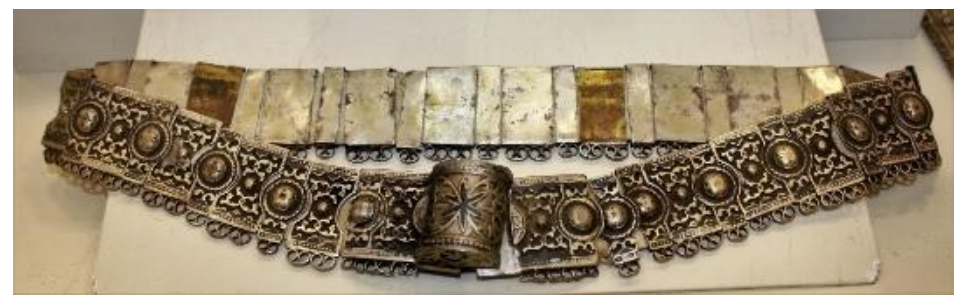

Fotoğraf 11:

Gümüş Kemer, Osmanlı Dönemi (18-19. yy), Envanter No: 3.3.78, Uzunluk: 71 cm, Genişlik: 3,5 cm.

\subsubsection{Gümüş Kemer}

Gümüş kemer, Kars Kafkas yöresinde sıklıkla karşılaşılan erkekli dişili levhalardan meydana getirilmiştir. Kemer bir dişili bir erkekli toplam kırk altı ana levhadan oluşmaktadır. Erkekli levhaların yüzeyi içleri boş kürecikler ile bezenmiştir. Dişili levhaların yüzeyi kabartma biçiminde daha küçük küreciklerle bezenmiştir. Kemeri oluşturan levhaların üzerinde kabartma tekniğinde rumi motifleri yer almaktadır. Levhaların birbirine daha sağlam tutturulması ve takan kişinin daha rahat hissetmesi için iç kısmına deri malzeme yerleştirilmiştir. Ancak deri kısmı günümüze ulaşmamıştır. Kemerin alt tarafında bir şerit halinde dolanan içe doğru kıvrılmış plakalar dizilmiştir. Plakalara takılmış dairesel şekilde ve iç kısmında tellerin kıvrılmasıyla oluşturulmuş sarkaçlar yer almaktadır. Kemer tokası, ortada bir gül motifi, yan kısımlarda yarım gül şeklinde telkâri tekniğinde bitkisel süslemelidir. Gül motifinin belirli boşluklarına gümüş topçuklar yerleştirilmiştir. Tokanın alt kısmında iki adet zincir ile sarkıtılmış dört adet dairesel formda içleri tellerle kıvrılmış sarkaçlar yer almaktadır. Sağlam olan eser üzerinde yer yer oksitlenmeler görülmektedir (Çiz. 9, Foto. 12-13).

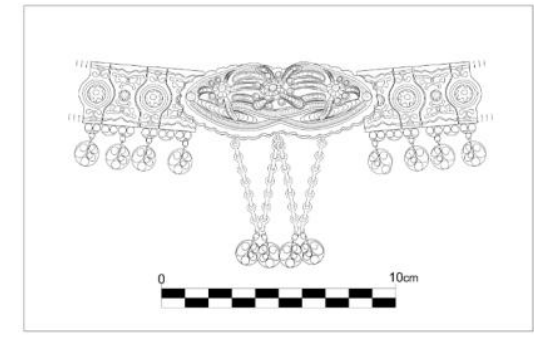

Çizim 9:

Gümüş Kemer Çizimi

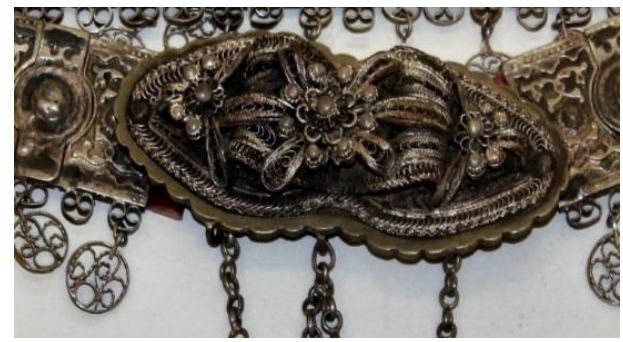

Fotoğraf 12:

Gümüş Kemer Detay1

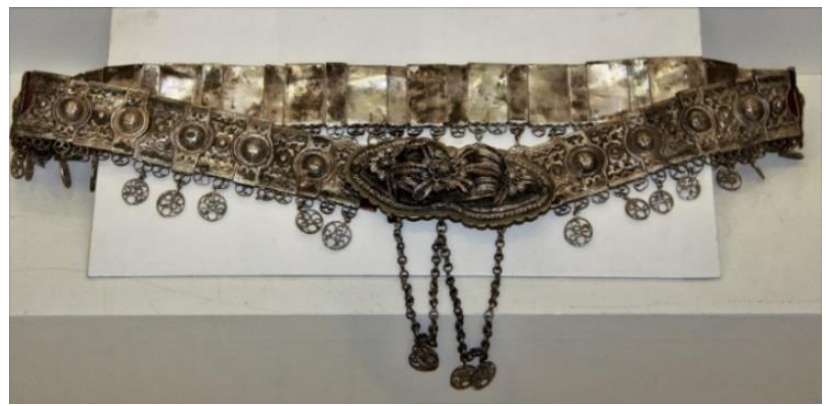

Fotoğraf 13:

Gümüş Kemer, Osmanlı Dönemi (18-19. yy), Envanter No: 1.5.77, Uzunluk: 85 cm, Genişlik: 3,5 cm.

\subsubsection{Gümüş̧ Kemer}

Kemeri meydana getiren levhaların bir tarafı erkekli bir tarafı dişili toplam otuz bir levhanın birleştirilmesi ile oluşturulmuştur. Her bir levhanın üzerinde kabartma biçiminde bir büyük, bir küçük kubbecik yer almaktadır. Kubbeciklerin alt ve üst tarafın a rumi motifleri yerleştirilmiştir. Rumilerin alt kısımları savat tekniğinde süslenmiştir. Kemerin üst tarafında her levhada üçer adet içe doğru kıvrılmış plakalar bir şerit halinde kemeri çevrelemektedir. Kemerin iç tarafında levhaların tutturulması için deri malzeme kullanılmıştır. Kemerin toka kısmı bir tarafa sabit yarım silindir şeklinde düzenlenmiş, ortasında kabartma tekniğinde altı kollu bir yıldız motifi yer almaktadır. Yıldız motifi savat tekniğinde bezenmiş ve iki yandan dört adet lale motifi ile süslenmiştir. Tam ve sağlam olan eser üzerinde yer yer oksitlenmeler görülmektedir (Çiz. 10, Foto. 14-15). 


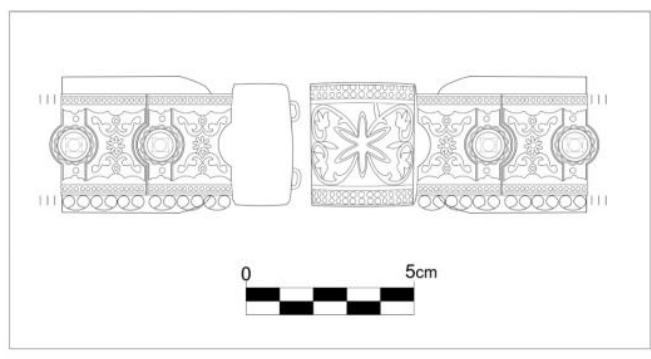

Çizim 10:

Gümüş Kemer Çizimi

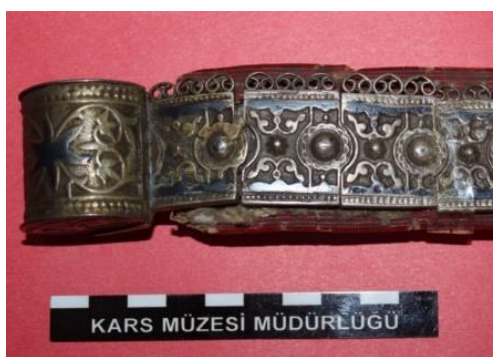

Fotoğraf 14:

Gümüş Kemer Detayı

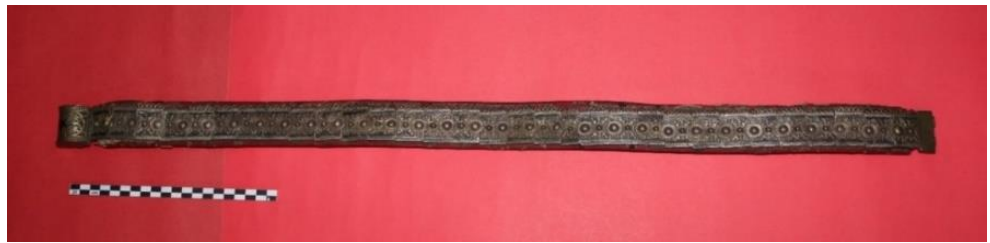

Fotoğraf 15:

Gümüş Kemer, Osmanlı Dönemi (18-19. yy), Envanter No: 4.20.72, Uzunluk: 76 cm, Genişlik: 3,2 cm.

\subsubsection{Bakır Kemer}

Bakır malzemeden yapılmış kemer toplam kırk sekiz ana levhanın birbirine geçirilmesi ile oluşturulmuştur. Levhalar bir tarafı erkekli bir tarafı dişili birbirine geçmeli bir biçimde yapılmıştır. Her levhanın orta kısmına kabartma biçiminde bir tane kubbecik yerleştirilmiştir. Kubbeciklerin etrafı levhalar boş kalmayacak biçimde rumi motifleriyle bezenmiştir. Levhaların alt ve üst kısımları savat tekniği ile bezenmiştir. Kemerin üst kısmında her levhada ikişer adet şerit halinde içe doğru kıvrılmış plakalar dizilmiştir. Kemerin iç tarafına levhaların birbirine tutturulması için deri malzeme yerleştirilmiştir. Kemer tokası yarım silindir formlu ortasında kabartma tekniğinde altı kollu bir yıldız motifi savat tekniğinde bezenmiştir. Yıldız motifinin iki yanında dört adet lale motifi yer almaktadır. Tokanın alt ve üst kısmı birer lale motifi ile bezenmiştir. Kemer tam ve sağlam bir biçimde günümüze ulaşmıştır (Çiz. 11, Foto. 16-17).

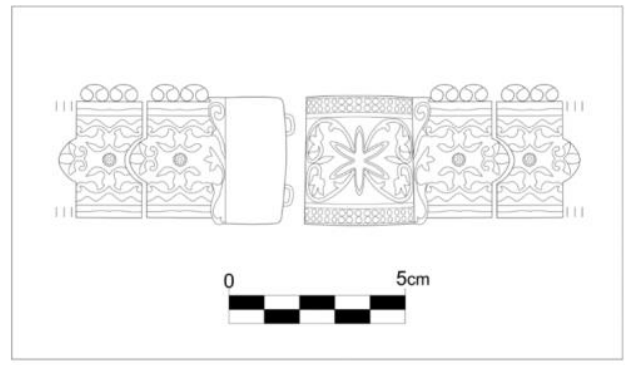

Çizim 11:

Bakır Kemer Çizimi

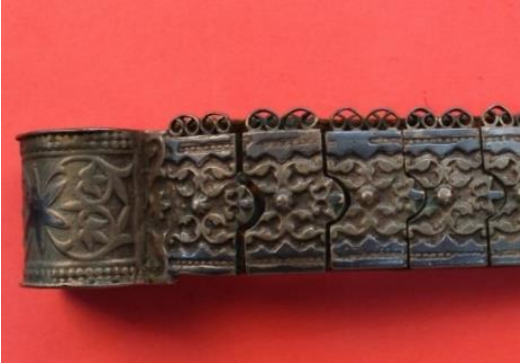

Fotoğraf 16:

Bakır Kemer Detay1

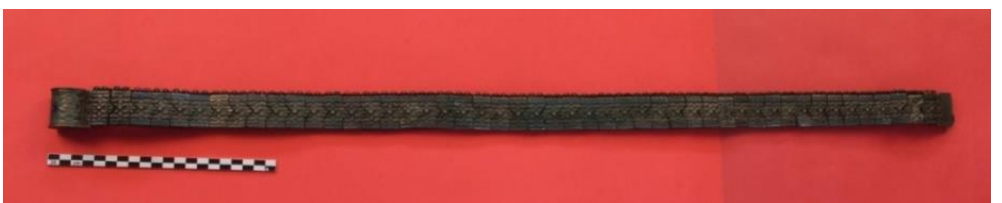

Fotoğraf 17:

Bakır Kemer, Osmanlı Dönemi (18-19. yy), Envanter No: 1.10.81, Uzunluk: 88 cm, Genişlik: 3,5 cm.

\subsubsection{Gümüş ve Iplik Kemer}

Kemer kuşağı iplikle dokunulmuş ve üzerine gümüş malzemeden yapılmış on bir adet spiral biçimde plakadan oluşmaktadır. Gümüş dilimler belirli aralıklarla iplik kuşağının üzerine yerleştirilmiş rumi motifleriyle süslenmiş savat tekniğinde bezenmiştir. Kemer tokası damla motifi şeklinde düzenlenmiş iki parçadan oluşmaktadır. Kemer tokası biri kuşağın sağ tarafına diğeri sol tarafına yerleştirilmiştir. Sağ tarafa yerleştirilen tokanın ucu yarım küre biçiminde düzenlenmiş ve arka tarafında kemerin birleştirilmesi için kanca yer almaktadır. Diğer tarafta kancanın takılacağı kanca yeri mevcuttur. Üzerinde yer alan rumi motifleri savat tekniğinde bezenmiştir. Kemer tokaları simetrik bir biçimde yapılmış orta kısımda savat tekniğinde Osmanlı tuğrası ve onu çevreleyen rumi motifleri ile bezenmiştir. Eser tam ve sağlamdır (Çiz. 12, Foto. 18-19). 


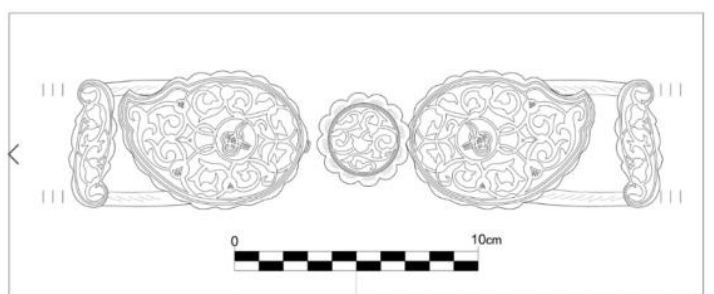

Çizim 12:

Gümüş ve İplik Kemer Çizimi

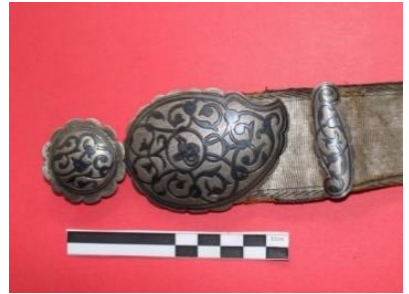

Fotoğraf 18:

Gümüş ve İplik Kemer Detay1

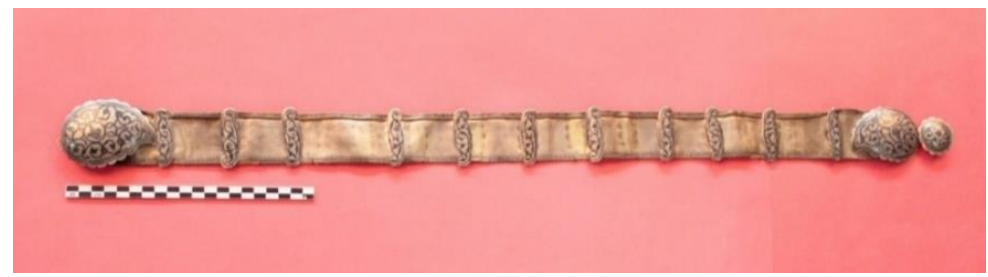

Fotoğraf 19:

Gümüş ve İplik Kemer, Osmanlı Dönemi (19. Yüzyıl Sonu), Envanter No: 2.1.1993, Uzunluk: 67 cm, Genişlik: $5 \mathrm{~cm}$.

\section{DEĞERLENDİRME VE SONUÇ}

İnsan ihtiyacının bir sonucu olarak doğan el sanatları ürünleri, zamanla gelişerek asıl kullanım amacının dışında insanların beğeni duygularının yansıtıldığı bir sanat eserine dönüşmüşlerdir. Bunlar arasında takılar, önemli bir grubu oluşturur. İlk çıktıklarında daha çok simgesel, büyü, tılsım ve liderlik gibi amaçlarla kullanılmış oldukları bilinse de zamanla kişisel zevklerin ortaya çıktığı birer sanat eserine dönüşmüşlerdir. Özellikle sembolik amaçlar, hoş görünme ve hediyeleşmeler açısından önemli bir araç olmuştur. Günümüzde bu amaçlarla takı kullanımı hala yoğun bir şekilde devam etmektedir. Kemer ve tokaları, bunlar arasında en güzel örneklerini sunarlar.

Kars Müzesi’nde bulunan kemer ve tokaları adlı çalışmada ele alınan örnekler, yapımında kullanılan malzeme, ait oldukları dönem, üretimlerinde uygulanan yapım ve süsleme tekniklerine göre değerlendirilmeye alınmıştır. Anılan değerlendirme ölçütleri dikkate alınarak, tekrara düşmeme adına mümkün olduğunca benzer eserler çalışmaya dâhil edilmemiştir. Bu kapsamda beş adet kemer ve yedi adet kemer tokasından oluşan toplam on iki eser incelenmiştir. Müzeye satın alma yoluyla kazandırılmış olan bu eserlerin bir kısmı müze deposunda tutulurken, bir kısmı da teşhir salonunda sergilenmektedir. Eserler arasında iki kemer tokası Selçuklu (Çiz. 1-2, Foto. 1,2,3,4), diğer eserler Osmanlı dönemine aittir. Yapımında kullanılan malzemeye göre değerlendirildiğinde, kemerlerden örnek no 4 bakır madeninden (Çiz. 11, Foto. 16-17), örnek no 5 iplik ve gümüşten (Çiz. 12, Foto. 18-19) üretilmişken, geriye kalan diğer tüm örnekler gümüş malzemeden yapılmıştır.

İncelemeye alınan 7 adet tokadan 2 tanesinin ayrıca altın suyuna batıııldığı gözlemlenmiştir (Çiz.1,2, Foto. 1,2,3,4). Altın suyuna batırılmış olan örnekler Selçuklu dönemine aittir. Selçuklu dönemine ait kemer tokaları dikdörtgen formlu ve tek bir levhadan oluşmaktadır. Bitkisel bezemeli olan bu iki eser, boyutlarında görülen farklılıklarla birbirinden ayrılmaktadır (Foto. $1,2,3,4)$. Geriye kalan diğer kemer tokalardan örnek no $1,2,5$ ve 7 'de yer alanlar tek bir levhadan meydana gelirken (Foto. 1,2,3,4,7,9), örnek no 3,4,6'daki tokalar ise iki levhadan oluşmaktadır (Foto. 5,6,8).

Kemer tokaları form açısından da zenginlik göstermektedir. Örnek no 3 'te yer alan kemer tokası stilize edilmiş yaprak formunda düzenlenmişken, örnek no 4 'teki kemer tokası damla motifi biçimindedir. Tanıtılan 5. örnekteki toka dikdörtgen 6'ncısı ise dairesel formludur. Örnek no 7'deki eser ise sivri uçlu konik bir forma sahiptir. Bunun yanı sıra, birer süs eşyaları oldukları için, takılar başta olmak üzere bu sınıfa giren ürünlerde genellikle süsleme teknikleri ön plana çıkmaktadır. Değerlendirilmeye alınan tokalarda kazıma (örnek no 1-2), kakma, mıhlama (örnek no 3); granüle ve telkâri (örnek no 4); savat (örnek no 5, 7); kabartma (örnek no 3- 6) süsleme tekniklerinin kullanıldığı tespit edilmiştir.

Kemer tokalarında bitkisel ve geometrik süslemeler ayrı ayrı veya tek başına kullanıldığı görülmektedir. Tokalardan örnek no 4 'teki (Foto. 6) eserde bitkisel ve geometrik süslemeler birlikte kullanılmışken, örnek no 1,2,3,5,6'daki tokalarda ise sadece bitkisel süslemelerin yer aldığı görülmektedir. Geriye kalan örnek no 7'de ise sadece geometrik süslemeler mevcuttur (Foto. 9).

Tokalar dışında çalışmada, 5 adet tokalarıyla birlikte kemer de incelemeye alınmıştır. Kemerlerden örnek no 4 bakır, örnek no 5 iplik ve gümüş, geriye kalan 3 kemer ise gümüş malzemeden yapılmıştır. İncelenen 5 adet kemer arasında örnek no 5 'teki eser, iplik ve gümüş malzemenin birlikte kullanılmasıyla oluşturulurken (foto. 18-19), diğer örnekler Kars yöresine özgü erkekli dişili levhaların birbirine tutturulmasıyla meydana getirilmiştir. Kemerleri oluşturan erkekli ve dişili levhaların üzerinde kabartma biçiminde birer kubbecik yerleştirilmiştir. Bu kubbeciklerin etrafı boş kalmayacak şekilde rumi motifleri ile süslenmiştir. Erkekli olan levhalardaki kubbecikler dişili levhalara göre daha büyük tutulmuştur. Kemerlerin tamamında yer alan tokalar, kemerin bir ucuna sabitken diğer tarafı kanca ile tutturulmaktadır. Kemerler form olarak birbirine benzese de bezeme teknikeri, boyutları, yapımında kullanılan malzeme ve tokaları ile farklılık göstermektedir. 
Kemerler arasında örnek no 2'deki kemerin tokası diğer eserlere göre farklılık göstermektedir. Oldukça yoğun bir süslemeye sahip olan bu kemer ve tokasından ayrıca sarkaçlar sarkıtılmıştır. Kemer tokası, ortada bir gül motifi, yan kısımlarda yarım gül şeklinde telkâri tekniğinde bitkisel süslemelidir. Gül motifinin belirli boşluklarına gümüş topçuklar yerleştirilmiştir. Tokanın alt kısmında iki adet zincir ile sarkıtılmış dört adet dairesel formlu içleri tellerle kıvrılmış sarkaçlar yer almaktadır (Foto. 12-13).

Kemerlerden örnek no 1,3,4'te yer alan kemerlerin tokaları yarım silindir formludur. Savat tekniğindeki tokaların merkezinde yer alan altı kollu yıldızın să̆ ve sol tarafında birbirine dolanan dört adet lale motifi yer almaktadır. Kaş kısmının alt ve üst bölümü de birer lale motifi ile süslenmiştir (Foto. 10,11,14,15,16,17). Kuşak kısmı iplik olan örnek no 5 'teki kemerin üzerinde gümüş malzemeden yapılmış on bir adet levha yerleştirilmiştir. Bu levhalar savat tekniğinde bitkisel süslemelerle bezelidir. Ayrıca kemer tokasında Osmanlı tuğrası bulunmaktadır (Çiz. 12, Foto. 18-19).

İncelenen kemerler arasında bitkisel ve geometrik süslemelerin birlikte kullanıldığı örneklerin yanı sıra, ayrı ayrı kullanıldığı eserler de mevcuttur. Örnek no 1,2,3,4'te yer alan eserlerde bitkisel ve geometrik süslemeler birlikte kullanılmışken, örnek 5'te sadece bitkisel süslemelere yer verilmiştir. Yapımında kullanılan süsleme teknikleri açısından da farklılık gösteren kemerlerden örnek no 1,3 ve 4'te savat ve kabartma, örnek no 2'de kabartma ve telkâri teknikleri birlikte kullanıldığı görülürken, örnek no 5 'te gümüş plakalar üzerinde sadece savatlama tekniğinde bezemeler yer almaktadır. Ayrıca örnek no 5'teki kemer dışında kalan örneklerde levhaların birbirine daha sağlam tutturulması ve takan kişinin kendini daha rahat hissetmesi için iç kısma deri malzeme yerleştirilmiştir.

Ele alınan tokalar grubu, form olarak dikdörtgen (örnek no 1,2,5), yaprak motifli (örnek no 3), damla motifli (örnek no 4), dairesel (örnek no 6), ve koni (örnek no 7) biçimlidirler. Kuşaklı tokalar ise yarım silindir (örnek no 1, 3, 4), gül (örnek no 2) ve damla (örnek no 5) motifi formludur.

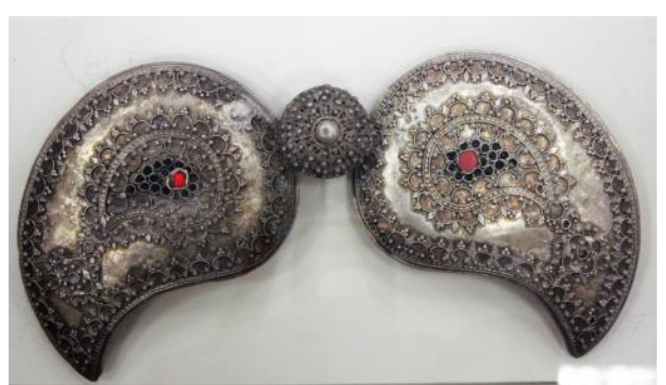

Örnek No 4:

Gümüş Kemer Tokası

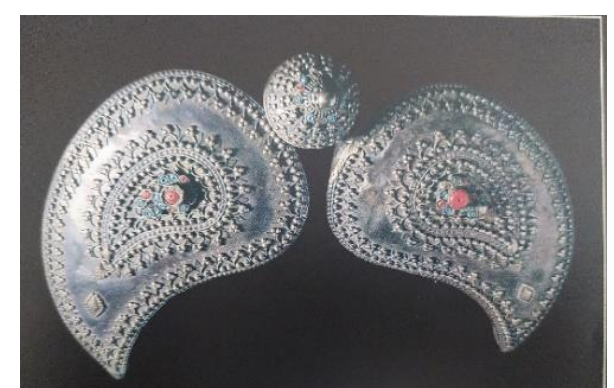

Fotoğraf 20:

Gümüş Kemer Tokası, M. Z. Kuşoğlu'ndan.

Form ve süsleme yönünden tokalar, benzer şekilde Anadolu'nun pek çok yöresinde üretildiğini söylemek mümkündür. Önek no 4'de yer alan eser ile Doğu Anadolu yöresine ait toka (Kuşoğlu, 1998: 107) örnek olarak verilebilir. İki kemer tokası da gümüş malzemeden yapılmıştır. Eserler form ve kompozisyon bakımından oldukça benzerlik göstermektedir. Kemer tokaları damla motifi şeklinde düzenlenmiş ve iki levhadan oluşmaktadır. Toka parçalarının birinde kilidi örten bir kubbecik yer alırken, diğer parçada ise tutturma kancası mevcuttur. Tokaların yüzeyinde granüle ve telkâri tekniğinde bitkisel ve geometrik süslemeler yer almaktadır. İki eserin merkezine telkâri tekniğinde yaprak motifi yerleştirilmiş ve ortalarında mıhlama tekniğinde kırmızı renkli birer taş monte edilmiştir. Örnek no 4'deki kırmızı taşın etrafında daha küçük siyah boncuklar yerleştirilmiş, Fotoğraf 20'deki eserde ise mavi ve kırmızı boncuklar yerleştirilmiştir. Ayrıca Fotoğraf 20'deki kemerin tokasında, damla motifinin hemen altında baklava dilimi şeklinde geometrik süsleme yer almaktadır.

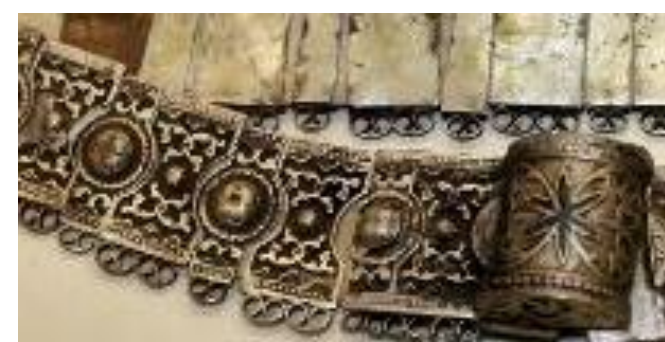

Örnek No 1:

Gümüş kemer

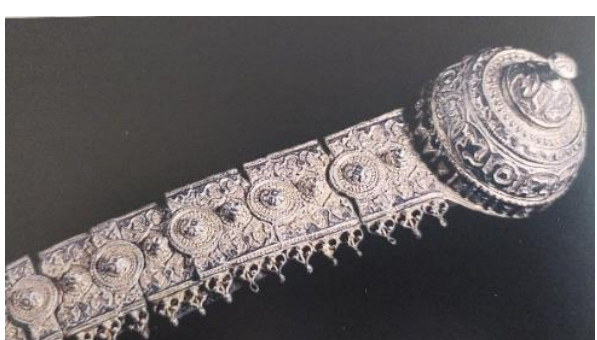

Fotoğraf 21:

Kafkasya yöresine ait kemer, M. Z. Kuşoğlu'ndan.

Türk halkının Orta Asya'dan beri kullandıkları kemerler, Anadolu'nun pek çok yöresinde benzer şekilde üretildiğini söylemek mümkündür. Çalışmaya dâhil edilen örnek no 1'deki kemer ile Kafkasya yöresine ait kemer (Kuşoğlu, 1998: 108) üzerinden bu benzerliği görmek mümkündür. Her iki kemer de Osmanlı dönemine ait gümüş malzemeden yapılmıştır. Tokaları dışında kemerler, form ve kompozisyon özellikleri bakımından oldukça benzerlik göstermektedir. Tokalardan örnek no 1'deki toka yarım silindir şeklindeyken, Fotoğraf 21 'deki örnek yarım dairevi formludur. Her ikisinde de kemeri meydana getiren kuşak 
kısımları erkekli ve dişili levhalardan oluşurken, erkekli levhaların yüzeyinde bir büyük, dişili levhalarda ise bir küçük kubbecik biçiminde kabartmalar yer almaktadır. İki kemer kuşağında da kabartma ve savat tekniğinde bitkisel süslemeler mevcuttur. Kemer levhalarının alt kısmında bir şerit halinde kuşağı çevreleyen ve içe doğru kıvrılma gösteren plakalar yer almaktadır.

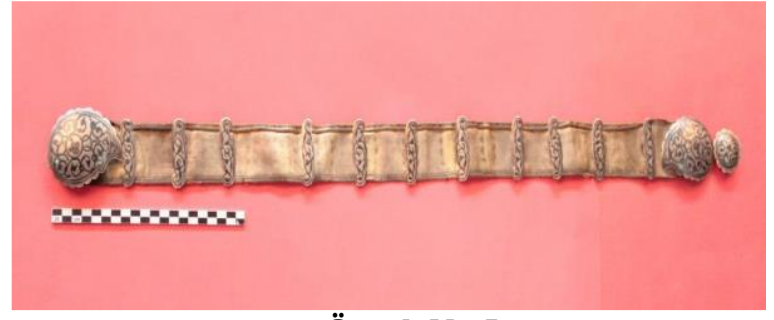

Örnek No 5:

Gümüş ve iplik kemer

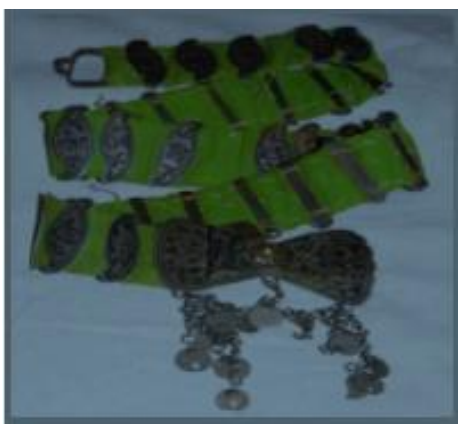

Fotoğraf 22:

Gümüş ve iplik kemer, E. M. Eroğlu'dan

Kemerler arasında Örnek no 5'de yer alan eserin bir benzeri Ege Üniversitesi Etnografya Müzesi'nde yer almaktadır (Eroğlu, 2013: 69). İki eser de 19. yüzyıl Osmanlı dönemine aittir. Eserler form, kompozisyon ve süsleme bakımından birbirine oldukça benzemektedir. Kemerlerin kuşak kısımları iplikten yapılmıştır. Bunlardan örnek 5’teki kuşak hardal sarısı, diğer örnek ise yeşil bir renge sahiptir. Her iki iplik kuşağının üzerine gümüşten yapılmış "S” kıvrımlı levhalar yer almaktadır. İki kemer üzerinde yer alan levhalarda savat tekniğinde bitkisel süslemeler yer almaktadır. Kemerlerin tokaları birbirinden farklıdır. Örnek no 5'in tokası damla motifi biçiminde düzenlenmiş üç parçadan oluşmaktadır. Fotoğraf 22'deki kemer tokası ise kurdele formunda düzenlenmiş ortadan boğum biçimindedir.

Sonuç olarak Türlerin Orta Asya'dan beri kullandıkları kemer ve tokalar Anadolu'da hayat bularak, Türk toplumunun sanatsal gelişim düzeyinin yanı sıra, kültürel değerlerini yansıtan ve günümüze ulaşmasını sağlayan birer belge niteliği taşımaktadır. Yöresel özellikler ve usta farklılığına rağmen Anadolu'da benzer form ve süslemelere sahip birçok kemer ve toka çeşidinin bulunması, ürünlerin aynı kültürden geldiğini göstermesi bakımından önemlidir. İncelenen eserler arasında yer alan kemerlerin kuşak kısımları Kafkas yöresine özgü erkekli ve dişili levhaların birleştirilmesiyle oluşturulmuştur. Farklı yörelerde yapılan karşılaştırmalar ile kemer ve tokalarının sanatsal üslupları ve süsleme anlayışının paralellik göstermesi bir etkileşimin söz konusu olduğunu da göstermektedir. Kemer ve tokaları giysinin bir tamamlayıcısı olarak hem işlevsel hem de hoş görünme gibi nedenlerle tarih boyunca hem erkekler hem de kadınlar tarafından kullanılmıştır. Özellikle erkeklerde işlevsel yönü ağır basmış, hançer, kılıç ve kese gibi malzemeleri tutmak amacıyla kullanılmıştır.

Bu araştırmada, Türk İslam dönemine ait Etnografik eserlerden bir grup kemer ve toka incelenerek, Kars Müzesi’ndeki bu eserlerin mevcut durumu ortaya konulmuştur. Bunun yanı sıra, bilimsel disiplin perspektifinde eserlerin tanıtılması, tarihlendirilmesi ve çözümlemeleri yapılarak belgelendirilmiştir.

\section{KAYNAKLAR}

Aral, S. (2017). Malatya Il Merkezinde Bulunan Madeni Taklar. Sanatta Yeterlilik Tezi, Anakara: Gazi Üniversitesi, El Sanatları Eğitimi Anabilim Dalı.

Baş, G., \& Çalış, E. (2020). Bitlis Kalesi Kazısı'nda Ele Geçen Bir Grup Madeni Takı. Sanat ve Kültür Tarihi Araştırmaları. ( Ed. E. Çalış ve R. Yelen). İstanbul: Hiper Yayın.

Başak, O. (2008). Taş Çağı'ndan Tunç Çă̆ı'na Anadolu'da Maden Sanatın Gelişimi ve Kullanımı. Atatürk Üniversitesi Güzel Sanatlar Enstitüsü Dergisi, 21, 15-33.

Bilgin, M. (2006). Takı Sektör Profili. İstanbul: İstanbul Ticaret Odası.

Baydar, T. (2020). Bursa Uluumay Vakfi Osmanlı Halk Klyafetleri ve Takılarl Ö̈zel Koleksiyonu'nda Yer Alan Kemer, Kemer Tokaları, Başlık ve Tepelikler. (Yayımlanmamış Yüksek Lisans Tezi). Samsun: Ondokuz Mayıs Üniversitesi.

Berkol, C. (2019). Tarihsel Süreçte Kemer ve Kuşak Kullanımı. Nişantaşı Üniversitesi Sosyal Bilimler Dergisi, 7(2), 42-62.

Çalış, E. (2018). Batman Müzesi’nde Bulunan Bir Grup Fibula. The Journal of Academic Social Science, 6, 81,271-282.

Çalış, E., \& Erk, A. (2020). Anadolu'da Bilezik Serüveninin Geleneksel Türk El Sanatları Açısından Önemi: Osmanlı Döneminden Bir Grup Örnek. Van Yüzüncü Yll Üniversitesi Sosyal Bilimler Enstitüsü Dergisi, 47, 139-156.

Çavuşoğlu, R. (2002). Urartu Kemerleri. Doktora Tezi. Erzurum: Atatürk Üniversitesi, Sosyal Bilimler Enstitüsü.

Eroğlu, E. M. (2013). Ege Üniversitesi Etnografya Müzesinde Bulunan Takıların Teknik Ve Tasarım Özelliklerinin Incelenmesi. (Yayımlanmamış Yüksek Lisans Tezi). İzmir: Dokuz Eylül Üniversitesi, Güzel Sanatlar Enstitüsü.

Günbay, N. (2019). Ankara Etnografya Müzesi’nde Bulunan Kemer Tokalarının İncelenmesi. (Yayımlanmamış Yüksek Lisans Tezi). Ankara: Gazi Üniversitesi, Güzel Sanatlar Enstitüsü. 
Görünür, L. (2010). Osmanlı İmparatorluğu’nun Son Döneminden Kadın Giysileri, Vehbi Koç Vakfi Sadberk Hanım Müzesi, İstanbul.

Işık, E. (2010). Eskişehir İli Sivrihisar Yöresi Takıları. (Yayımlanmamış Yüksek Lisans Tezi). Ankara: Gazi Üniversitesi.

Kuşoğlu, M. Z. (1998). Tılsımdan Takıya. İstanbul: Pimapen Kültür Evi Yayınları.

Köroğlu, G. (2004). Anadolu Uygarlıklarında Takı, İstanbul: Türk Eskiçağ Bilimleri Enstitüsü Yayınları.

Megep, (2006). Kuyumculuk Teknolojisi Takının Gelişimi, Ankara: Milli Eğitim Bakanlığı Yayınları.

Öztürk, Ö. (2012). Geleneksel Urfa Giysilerinde Kullanılan Altın ve Gümüş Kemerlerin İncelenmesi. (Yayımlanmamış Yüksek Lisans Tezi). Ankara: Gazi Üniversitesi, Eğitim Bilimleri Enstitüsü.

Türkoğlu, S. (2008). Tarih Boyunca Anadolu'da Giyim- Kuşam. M. T. Koçkar (Ed.) Halk Kültürü’nde Giyim-Kuşam ve Süslenme Uluslararası Sempozyumu Bildirileri (s. 22). Eskişehir: Osmangazi Üniversitesi.

Ünlerşen, H. (2015). Kayseri Selçuklu Uygarlığı Müzesi’nde Bulunan Kemer Tokalarl. (Yayımlanmamış Yüksek Lisans Tezi). Konya: Necmettin Erbakan Üniversitesi, Sosyal Bilimler Enstitüsü.

Yılmaz, T. (2015). Türk Takı Sektöründe Uygulanan Halkla İlişkiler Faaliyetlerinin Mükemmel Halkla İlişkiler Kuramı Bağlamında İncelenmesi. (Yayımlanmamış Yüksek Lisans Tezi). İstanbul: İstanbul Aydın Üniversitesi, Sosyal Bilimler Enstitüsü.

Yavaş, A. (2012). Kubad-Abad Sarayı'nda Bulunan Kemer ve Askı Tokaları, Turkish Studies, 7/3, 2635-2648. 